Ichak Adizes', Dušanka Rodić1, Mladen Čudanov²

${ }^{1}$ Adizes Institute, Santa Barbara, California, USA

2University of Belgrade, Faculty of Organizational Sciences, Serbia

\title{
Estimating Consultant Engagement in the Corporate Life Cycle: Study of the Bias in South Eastern Europe
}

DOI: 10.7595/management.fon.2017.0015

\begin{abstract}
This paper surveys perception bias regarding the timing of proactive consultant engagement. It aims to improve the efficiency and effectiveness of consultant engagement. Research is based on the primary dataset from South Eastern Europe and the secondary dataset which is used for comparison as the real life cycle phase of consultant engagement. Adizes life cycle model provided our theoretical framework. After data were checked for normality, t-test was used for hypotheses confirmation/rejection. The T-test confirmed the existence of negative bias in early life cycle phases, onesamplet $(118)=-16,232, p=0.000$. Significant differences were found for bias of early phases in organisations founded less than 25 years ago $(M=-0.301, S D=0.22)$ and organisations founded more than 25 years ago $(M=-0.396, S D=0.24) ; t(110)=2.072, p=0.041$; also, absolute bias in organisations founded less than 25 years ago $(M=1.32, S D=0.27)$ and organisations founded more than 25 years ago $(M=1.20, S D=0.31)$ is significantly different $\mathrm{t}(110)=-2.204, \mathrm{p}=0.030$. Significant differences were not found between early life cycle stages bias of consultants $(M=-0.374, S D=0.26)$ and users of consulting services $(M-0.368, S D=0.22) ; t(117)=$ $0.475, p=0.636$ but absolute bias in organisations with less than 25 years of chronological age $(M=1.32, S D=0.27)$ and organisations with more than 25 years of chronological age $(M=1.20, S D=0.31)$ is significantly different $t(117)=-$ 1.348, $p=0.180$. This research finds strong bias in estimation of life cycle phase as time for engagement of proactive consulting services. The timing for consultant engagement is not often correctly estimated by the users of the service, so those services can be engaged as preventive before issues arise in organisation and become a crisis at the tip of the organisational iceberg. The main limitations of our research are that we do not have true random sample and that data is from South Eastern Europe which limits broader generalization.
\end{abstract}

Keywords: Consulting, Consultant engagement, Adizes life cycle, Corporate life cycle, South Eastern Europe, Management

JEL Classification: L89, L29, L84, M10, M19

\section{Introduction}

This paper is aimed at describing perception bias regarding the timing of proactive consultant services engagement. We define the timing of consultant services as the period in the organisational life cycle when the consulting services are engaged. Consultants, managers and employees often have different opinions on what the best time for engagement is, in comparison with actual engagement. We define the proactive consultant services engagement as the business collaboration between user and provider of those services, enticed without the pressure of either:

- short-term organisational objectives or

- external stakeholders exerting decision power for organisational matters. 
In case the organisation is under pressure of either or both factors, consultant services engagement can be defined as reactive (e.g., due to corporate bankruptcy/restructuring, failure to perform short-term business activities or obligation to achieve externally defined quality standard). In that case it has few other options but to engage consultant services, and that class is not the topic of this study. A metaphor can be drawn with medical services engagement: the patient can engage them proactively, perform regular medical checkups and visit medical specialists without significant, or even without any pressure regarding health, or reactively where the patient is obliged to receive medical services in order to solve the observed health issues. Timing is an important and much more voluntarily adjustable factor in proactive engagement, whatever the reasons for that engagement are. That is why we investigate timing bias - internal and external perception of the appropriateness of proactive consultant engagement can influence actual consultant engagement in organisations.

Related to that we have posted three different hypotheses we can check using our data:

- H1: Expectation of proactive consultant engagement is negatively biased for early phases of corporate life cycle and positively biased for late phases of corporate life cycle

- H2: Bias differs in accordance with chronological age - in organisations founded earlier employees estimate less chance for younger life cycle phases than in organisations with a longer chronological age

- H3: There is a difference in estimation bias between consultants and users of consulting services

\section{Literature Review}

To understand better what can cause bias in estimating timing of consultant engagement during the organisational life cycle, we need to focus on a) the nature of consultant engagement and b) organisational life cycle in the existing research discourse.

\subsection{The Nature of Consultant Engagement}

Kubr (2002) defines management consulting as a useful professional service that helps managers to analyse and solve practical problems faced by their organisations, improve organisational performance, learn from the experience of other managers and organisations, and seize new business opportunities. The way in which management consulting improves organisational competitiveness can be observed from the client company's need for knowledge they lack inside the company, which they try to compensate by hiring management consultants. As a process, management consulting could be described as an analysis of existing organisational problems and the development of plans for improvement in order to improve its performance. Management consultancy could be considered as a creation of value for organisations (Turner, 1982) by applying knowledge, techniques and assets to improve organisational performance. The knowledge system in consulting organisations has three interacting knowledge elements according to Werr and Stjernberg (2003): methods and tools, providing a common language and knowledge structure; earlier solved client cases with narrative knowledge; and the individual consultant experience on how to adapt methods, tools and cases to a specific case.

Simon and Kumar (2001) summarise that main reasons for hiring consultants are: insufficient in-house expertise, independent/objective advice, gaining additional help/resources, insufficient manpower in-house and quick resolution of issues. This insufficient in-house expertise given as objective advice is usually confirmed in practice which gives the credibility to managerial consultants who are hired to help the company (Kipping \&Clark 2012). Consultants provide the so called "bridging services" where they bridge the gap of insufficient company's internal expertise on the one hand, and the pool of knowledge based on experience and successful application on cases, on the other hand. The way of bridging the gap with external consultant engagement has proven to be more economical than only by efforts of client firms themselves (Bessant \&Rush, 1995). If managers and outside advisers work out in advance what is expected of each party during their work together, the chances of solving problems are improved. According to McLachlin (2012), quality as the most important dimension of consulting service depends on consultant reliability, or, in other words, "doing what you say you will do". For consulting engagements, reliability means meeting agreed-on goals as judged for service quality by the customer. Bronnenmayer, Wirtz and Göttel (2016) stay on that line of previous research and summarize common vision with the client, intensity of collaboration, provided resources and top management support, and consultant expertise as the main factors of management consultant engagement success. 
Six universal factors of consultancy engagement as summarised by McLachlin (1999) are:

- Consultant integrity - the means to put the client's needs first, but not necessarily the same as doing what the client asks. It refers to putting the client's best interests first, which could mean convincing the client that long-term needs are more important than immediate wants.

- Client readiness and involvement - in order that consulting engagement be a success, it is necessary but not sufficient that the client should be involved and ready to change.

- Clear agreement directs the client to think clearly and realistically regarding promises and expectations, improving professional service quality as defined by Zeithaml, Valarie, Parasuramanand Berry (1990), i.e., a better match between perceptions of received services and expectations the client had of them.

- Client control - major consulting disasters can occur when the client loses or neglects to establish control of the engagement.

- Consultant's competence includes knowing one's limits and acting in accordance with one's capabilities.

- Fit - organisation should hire the consultant with a style, beliefs, values and approach that are appropriate for the desired assignment.

\subsection{Corporate Life Cycle}

The idea of similarity between organisations and living organisms was founded as early as 1890 , by famous economist Alfred Marshall (1890). In his research firms were compared to trees in the forest, using a beautiful metaphor: "But here we may read a lesson from the young trees of the forest as they struggle upwards through the benumbing shade of their older rivals". He describes organisations in youth as they struggle to grow and reach better positions until they teach the top-tier and start to stagnate, decline and eventually die. The theoretical background for corporate life cycle idea was established by biologist Ludwig von Bertalanffy. His early work during 1920's introduced general systems theory approach (Weckowicz, 2000) and the earliest reference in English was published in 1933 (Bertalanffy, 1933). It was followed by his general systems theory, which put a framework where it was possible to research further similarities between living organisms and organisations. However, concrete idea that organisations pass through life cycle as living organisms was published two decades later (Boulding, 1950), and Boulding is held to be the first author to explicitly analyse the life cycle of the organisation within this framework (Ionescu\&Negrusa, 2007).

Table 1. Organisational life cycle literature review

\begin{tabular}{|lcr|}
\hline Life cycle stages & \multicolumn{1}{c}{ Main idea } & Reference \\
\hline $\begin{array}{l}\text { Growth, competition, top } \\
\text { position, stagnation, decline } \\
\text { and (eventually) death }\end{array}$ & $\begin{array}{r}\text { Growing trees in the forest as the } \\
\text { analogy for the firm. }\end{array}$ & (Marshall, 1890) \\
\hline Birth, growth, decline, death & $\begin{array}{c}\text { Organisations follow the same life } \\
\text { cycle as living organisms. }\end{array}$ & (Boulding, 1950) \\
\hline $\begin{array}{l}\text { Born stage, growth - } \\
\text { establishing of legitimacy, } \\
\text { rapid growth -innovation and } \\
\text { expansion, aging phase } \\
\text { formalisation and control }\end{array}$ & $\begin{array}{r}\text { Describes the dynamics of } \\
\text { bureaucratic organisations. }\end{array}$ & (Downs, 1967) \\
\hline $\begin{array}{l}\text { Birth, youth - developing, } \\
\text { stability and reputation, and } \\
\text { maturity. }\end{array}$ & $\begin{array}{r}\text { Organisation goes through stages in } \\
\text { the life cycle, and thus the crises which } \\
\text { occur in every organisation could be } \\
\text { predicted according to the stage. }\end{array}$ & (Lippitt\&Schmitdt, 1967) \\
\hline $\begin{array}{l}\text { Informal "one-man-show," } \\
\text { formalised bureaucracy, and } \\
\text { diversified conglomerate }\end{array}$ & $\begin{array}{l}\text { Organisational life } \\
\text { cycle is based on strategy } \\
\text { and structure. }\end{array}$ & \\
\hline
\end{tabular}




\begin{tabular}{|c|c|c|}
\hline Life cycle stages & Main idea & Reference \\
\hline $\begin{array}{l}\text { High-growth phase } \\
\text { and low-growth (mature) } \\
\text { phase }\end{array}$ & $\begin{array}{l}\text { Researched how dividends fit in the life } \\
\text { cycle followed by the empirical } \\
\text { evidence on dividend policy as it } \\
\text { relates to the life cycle theory. The } \\
\text { value-maximizing firm should maintain } \\
\text { a zero pay-out ratio at the initial } \\
\text { stages and increase the pay-outs to } \\
100 \% \text { upon reaching maturity. }\end{array}$ & (Mueller,1972) \\
\hline $\begin{array}{l}\text { Creativity, direction, } \\
\text { delegation, coordination } \\
\text { and collaboration } \\
\text { stage }\end{array}$ & $\begin{array}{l}\text { The speed at which an organisation } \\
\text { experiences phases of evolution and } \\
\text { revolution is closely related to the } \\
\text { market environment of its industry. } \\
\text { Each phase is both an effect of the } \\
\text { previous and a cause for the next. }\end{array}$ & (Grainer, 1972) \\
\hline $\begin{array}{l}\text { First stage of new } \\
\text { agency, second stage } \\
\text { of new agency }\end{array}$ & $\begin{array}{l}\text { Based on the analysis of problems in } \\
\text { complex public organisations. } \\
\text { Problems provide criteria for } \\
\text { identifying the functional effects of the } \\
\text { efforts of an organisation both } \\
\text { internally and as they contribute to the } \\
\text { goals of larger systems. }\end{array}$ & (Lyden, 1975) \\
\hline $\begin{array}{l}\text { Primitive system stage, } \\
\text { stable organisation stage } \\
\text { and elaborative supportive } \\
\text { structure stage }\end{array}$ & $\begin{array}{c}\text { Organisational } \\
\text { structures develop over } \\
\text { time frame of organisational } \\
\text { growth. }\end{array}$ & (Katz \&Kahn, 1978) \\
\hline $\begin{array}{l}\text { Courtship, infancy, go-go, } \\
\text { adolescence, prime, stability, } \\
\text { aristocracy, recrimination } \\
\text { (early bureaucracy), } \\
\text { bureaucracy and death. }\end{array}$ & $\begin{array}{l}\text { Comparison of company life cycle } \\
\text { to living organism life cycle, with the } \\
\text { crucial exception - the company does } \\
\text { not have to die, it can be rejuvenated. } \\
\text { Organisations go through the } \\
\text { normal struggles and difficulties } \\
\text { accompanying each stage. }\end{array}$ & (Adizes, 1979) \\
\hline $\begin{array}{l}\text { Initiation, } \\
\text { innovation and } \\
\text { institutionalisation. }\end{array}$ & $\begin{array}{l}\text { The author finds organizational } \\
\text { features causing success as an } \\
\text { innovation in the short run } \\
\text { incompatible with requirements for the } \\
\text { survival in the longer run. The author } \\
\text { proposes biographical approach to } \\
\text { organisational analysis. }\end{array}$ & (Kimberly,1979) \\
\hline $\begin{array}{l}\text { Entrepreneurial stage, } \\
\text { collectively, formalisation and } \\
\text { elaboration of structure stage. }\end{array}$ & $\begin{array}{l}\text { Changes that occur in organisations } \\
\text { follow a predictable pattern that can be } \\
\text { characterized by developmental } \\
\text { stages. The stages are sequential, and } \\
\text { changes target: cognitive orientations } \\
\text { of organisation members, } \\
\text { organisational structures and } \\
\text { environment relation. }\end{array}$ & (Quinn\&Cameron, 1983) \\
\hline $\begin{array}{l}\text { Existence, survival, success, } \\
\text { take-off and resource maturity }\end{array}$ & $\begin{array}{l}\text { Small business growth depends on } \\
\text { success factors such as: business } \\
\text { size, diversity, complexity, owner's } \\
\text { management style and } \\
\text { organisational goals. }\end{array}$ & (Lewis\&Churchill, 1983) \\
\hline $\begin{array}{l}\text { Birth, growth, } \\
\text { maturity, revival } \\
\text { and decline }\end{array}$ & $\begin{array}{l}\text { Each stage will manifest integral } \\
\text { complementariness among variables } \\
\text { of environment, strategy, structure and } \\
\text { decision making methods; these are } \\
\text { four classes of variables to differentiate } \\
\text { organizational stages }\end{array}$ & (Miller\&Friesen, 1984) \\
\hline $\begin{array}{l}\text { Inception, survival, } \\
\text { growth, expansion } \\
\text { and maturity. }\end{array}$ & $\begin{array}{l}\text { The transition from one stage } \\
\text { to the next requires change } \\
\text { accompanied by crisis. }\end{array}$ & (Scott\&Bruce, 1986) \\
\hline
\end{tabular}




\begin{tabular}{|c|c|c|}
\hline Life cycle stages & Main idea & Reference \\
\hline $\begin{array}{l}\text { Growth, decline, } \\
\text { death }\end{array}$ & $\begin{array}{c}\text { Focuses on causes and } \\
\text { consequences of growth and declines } \\
\text { processes in organisations focused on } \\
\text { the role of environmental, structure } \\
\text { and individual factors. }\end{array}$ & (Whetten, 1987) \\
\hline $\begin{array}{l}\text { Entrepreneurial Stage, } \\
\text { Collectivity Stage, } \\
\text { Control Stage, } \\
\text { Elaboration of } \\
\text { Structure-Decline } \\
\text { Stage }\end{array}$ & $\begin{array}{l}\text { Emphasis is on two outcomes of } \\
\text { formalisation: administrative efficiency, } \\
\text { and influence. Formalisation (as the } \\
\text { efficiency) contributes to effectiveness } \\
\text { early in an organisation's history. } \\
\text { Later in the life cycle, formalisation } \\
\text { (as the influence) may contribute } \\
\text { to organisational ineffectiveness } \\
\text { and decline. }\end{array}$ & (Walsh\&Dewar, 1987) \\
\hline $\begin{array}{l}\text { Conception, Investment, } \\
\text { Incorporation, Investments, } \\
\text { Incorporation, Experiments, } \\
\text { Systematic production, Social } \\
\text { network, Collaborative inquiry, } \\
\text { Foundational community of } \\
\text { inquiry, Liberating disciplines }\end{array}$ & $\begin{array}{l}\text { Analogous to E. Erikson's (1959) } \\
\text { theory of individual development. The } \\
\text { main idea is to provide a new } \\
\text { perspective on the problems of } \\
\text { creating new organisations, changing } \\
\text { bureaucratic organisations, and } \\
\text { envisioning qualitatively different kinds } \\
\text { of organising. The final phase enables } \\
\text { rebirth by awareness of and skills for } \\
\text { resolving gaps between mission, } \\
\text { strategy and outcomes. }\end{array}$ & $\begin{array}{r}\text { (Rooke\&Torbert 1998; } \\
\text { Sherman \&Torbert 2000; } \\
\text { Cacioppe\& Edwards, 2005) }\end{array}$ \\
\hline $\begin{array}{l}\text { Existence, survival, } \\
\text { success, renewal, } \\
\text { decline }\end{array}$ & $\begin{array}{l}\text { Resembling general Miller and } \\
\text { Friesen viewpoint and a } 5 \text { stage } \\
\text { model, develops a scale to classify } \\
\text { organisations, and examines } \\
\text { relationships between organisational } \\
\text { life cycle, competitive strategy, } \\
\text { and performance. }\end{array}$ & $\begin{array}{r}\text { (Lester, } \\
\text { Parnell\&Carraher, } \\
2003)\end{array}$ \\
\hline $\begin{array}{l}\text { The absorptive capacities: } \\
\text { ignorance, awareness, } \\
\text { knowledge, implementation. } \\
\text { The tipping points: Market } \\
\text { entry, operational } \\
\text { improvement, people } \\
\text { management, obtaining } \\
\text { finance, formal systems, } \\
\text { strategy. }\end{array}$ & $\begin{array}{l}\text { As analogy to life cycle stages they chose } \\
6 \text { tipping points with two dimensions } \\
\text { (absorptive capacity and tipping point } \\
\text { solutions). This provides a framework } \\
\text { within which to examine the growth needs } \\
\text { of firms. Their reconceptualization of firm } \\
\text { growth contrasts with the linear model } \\
\text { described by the organismic metaphor } \\
\text { and proposes that, over time, firms } \\
\text { encounter tipping points which are the } \\
\text { consequence of growth or of } \\
\text { environmental changes. To navigate } \\
\text { beyond the tipping point, the firm must } \\
\text { have the capability to identify, acquire and } \\
\text { apply new and requisite knowledge to } \\
\text { resolve the new challenges and succeed } \\
\text { in a competitive environment. }\end{array}$ & $\begin{array}{r}\text { (Phelps, } \\
\text { Adams\&Bessant, } \\
2007)\end{array}$ \\
\hline $\begin{array}{l}\text { Start-up, growth, } \\
\text { maturity, and decline }\end{array}$ & $\begin{array}{c}\text { Follow the framework of the resource- } \\
\text { based theory to explain relations between } \\
\text { managers and firm's resources. They use } \\
\text { and explain synthesis of existing life } \\
\text { cycle research. }\end{array}$ & $\begin{array}{r}\text { (Sirmon, Hitt, } \\
\text { Ireland\&Gilbert, 2011) }\end{array}$ \\
\hline $\begin{array}{l}\text { Introduction, Growth, } \\
\text { Maturity, Saturation, } \\
\text { Recession }\end{array}$ & $\begin{array}{l}\text { Synthesize earlier theoretical research } \\
\text { in order to connect life cycle with } \\
\text { organisational structure management } \\
\text { and transaction costs. }\end{array}$ & $\begin{array}{r}\text { (Gurianova, } \\
\text { Gurianov\&Mechtcheriakova, } \\
2014)\end{array}$ \\
\hline $\begin{array}{l}\text { Start-up phase, phases of } \\
\text { expansion, maturity and } \\
\text { subsequent diversification } \\
\text { (or decline) }\end{array}$ & $\begin{array}{l}\text { Life cycle is a unique configuration } \\
\text { of variables related to organisation } \\
\text { context, strategy, and structure. The } \\
\text { number and nature of the stages } \\
\text { vary extensively. }\end{array}$ & (Hanks, 2015) \\
\hline $\begin{array}{l}\text { Inception, High growth, } \\
\text { Maturity }\end{array}$ & $\begin{array}{l}\text { The author synthesises the work of the } \\
\text { previous authors to suggest a usable } \\
\text { model generic to all organisations. }\end{array}$ & (Tam\&Gray, 2016) \\
\hline
\end{tabular}


The focus of this paper will be on Adizes organisation life cycle model due to available data. In the focus of the whole Adizes methodology is change as the perpetual process. The corporate life-cycle stages that Adizes (2004) describes in his model provide a useful basis for understanding a fundamental perspective of organisational development, change, and the principles which cause organisational ageing. Adizes corporate life cycle theory identifies two common causes; one is that most phenomena, even stars (which are not living beings) have their own life cycles, and the other common denominator is change and disintegration as a natural consequence of the changing process. Adizes adopted the approach present in the chaos theory that problems are manifestations of disintegration caused by the change (Masterpasqua\&Perna, 1997), and then he used that approach to look at the organisational developmental stages through the nature of problems the organisation is to overcome. The essence in this conclusion, according to Adizes, is: if we assume that every system has its own life cycle, as they change progressing along their life cycle, the system follows predictable patterns of behaviour. At each stage, the system manifests certain struggles, certain difficulties or transitional problems - they must overcome.

\section{Methods}

The empirical part of this paper is based on the comparison between direct perception survey and state of the art in the consulting industry. Primary data were gathered by the questionnaire, developed under general guidelines (Saris\&Gallhofer 2014) and guidelines to diminish measurement error (Bagozzi, Yi and Phillips 1995). It was distributed to consultants and managers in South east Europe, in Bosnia and Herzegovina, Croatia, Montenegro, Serbia, Slovenia, based on the earlier, wider research (Adizes, Cudanov\&Rodic, 2017) which is focused on general trends of proactive consulting service engagement timing. Overall, 119 valid responses were gathered. Compared to that general research, this research used the extended base of secondary data and is focused on individual level details and differences of perception among the groups of participants in the primary research. The replies gathered in the survey regarding life cycle were normalised, and then average probability was calculated for each participant in the survey and for each life cycle phase. The secondary data were provided by the Adizes institute, and is used for comparison of actual consultant engagement. Bias was calculated for each participant in the survey as a difference between perceived probabilities of proactive consultant engagement at each stage of the life cycle and the secondary data of act. It resulted in a database where each survey participant had bias for perception of probability of consultant engagement for each life cycle phase which could be compared to other participant organisational and socio-demographic traits.

From this database we have derived two variables - Early life cycle phases bias as a sum of Courtship, Infancy, Go-go, Adolescence and Prime stage bias, and Late life cycle phases bias as a sum of Stability, Aristocracy, Reprimation, Bureaucracy and Death stage. Since probabilities of consultant engagement were complementary to 1 , as are the perceived probabilities after normalisation, those two variables are mirrored, and an analysis is performed only for one variable - analysis for another variable provides the same results with inverse signs. Another variable we tested was Life cycle phases absolute bias, as a sum of absolute values of probability estimation errors for each life cycle phase (both early and late). That variable tells us how wrong overall estimation of probabilities was given by actor with different sociodemographic characteristics and organisational role (e.g., consultant, employee, manager). Kolmogorov-Smirnov test was used to check distribution of our variables. Normal distribution was confirmed and two sample groups, divided by chronological age/estimator in a quasi-experimental design (Cook, Campbell\&Day1979) were similarly of the same size, a parametric one sample, as well as independent samples t-test was used in order to establish the difference for our variables according to the recommendations (Krishnaswamy, Sivakumar, \&Mathirajan, 2004; Saunders, Lewis\&Thornhill, 2011; Zikmund, Babin, Carr\&Griffin, 2012).

\section{Results}

Our variables Early life cycle phases bias and Life cycle phases absolute bias were checked for normal distribution. Kolmogorov-Smirnov test has confirmed normal distribution for the first variable (Test statistic 0.694 , asymptotic significance 0.721 ),$M=-0.357 \mathrm{SD}=0.24$, as well for the second variable (Test statistic 1.057, asymptotic significance 0.214$), M=1.276 \mathrm{SD}=0.29$. 
Our first hypothesis, H1: Expectation of consultant engagement is negatively biased for early phases of life cycle, and positively biased for late phases of life cycle was tested using one sample t-test, and hypothesized mean $=0$, while sample parameters for the variable Early life cycle phases bias were $\mathrm{M}=$ $0.3569, \mathrm{SD}=0.2398, \mathrm{SE}=0.0220$. T-test gave results of onesamplet(118) $=\mathbf{- 1 6 , 2 3 2}, \mathbf{p}=\mathbf{0 . 0 0 0}$, as presented in the following table.

Table 2. One sample t-test for early life cycle phases bias

\begin{tabular}{|c|c|c|c|c|c|c|}
\hline & \multicolumn{6}{|c|}{ Test Value $=0$} \\
\hline & \multirow[t]{2}{*}{$\mathrm{t}$} & \multirow[t]{2}{*}{ df } & \multirow[t]{2}{*}{$\begin{array}{l}\text { Sig. } \\
\text { tailed })\end{array}$} & \multirow[t]{2}{*}{$\begin{array}{l}\text { Mean } \\
\text { Difference }\end{array}$} & \multicolumn{2}{|c|}{$\begin{array}{l}\text { 95\% Confidence Interval of the } \\
\text { Difference }\end{array}$} \\
\hline & & & & & Lower & Upper \\
\hline $\begin{array}{l}\text { Early life cycle phases } \\
\text { bias }\end{array}$ & $\begin{array}{ll}- \\
16,2\end{array}$ & 118 & 0.000 & 0.3569 & 0.4004 & 0.3133 \\
\hline
\end{tabular}

Regarding that, we can confirm our Hypothesis $1(p<0.001)$, and conclude that according to our sample real proactive consultant engagement is $35.69 \%$ higher in early life cycle phases than it is expected by employees and consultants.

Our Hypothesis 2: Bias differs in accordance with chronological age - in organisations founded earlier employees estimate less chance for younger life cycle phases than in organisations with longer chronological age, was tested using two-sample t-test, with split point of 25 years since the founding of the organisations. Organisational age is not determined by chronological age; this classification instead shows how many years of external experience the organisation has managed to gather, as a possible factor of influence for bias in estimating a life cycle phase for proactive consultant engagement. That split point splits organisations in two groups of roughly similar size, which was confirmed on our sample.

Significant differences were found for bias of early phases in organisations founded less than 25 years ago $(M=-0.301, S D=0.22)$ and organisations founded more than 25 years ago $(M=-0.396, S D=0.24) ; t(110)=$ 2.072, $p=0.041$.

Also, absolute bias in organisations founded less than 25 years ago $(M=1.32, S D=0.27)$ and organisations founded more than 25 years ago $(M=1.20, S D=0.31)$ is significantly different $t(110)=-2.204, p=0.030$.

Table 3. Two samples according to chronological age

\begin{tabular}{|l|c|c|c|r|r|}
\hline & ChronologicalAge & $\mathrm{N}$ & Mean & Std. Deviation & Std. Error Mean \\
\hline \multirow{2}{*}{ Early life cycle phases bias } & $>=25$ & 44 & -0.3009 & 0.2215 & 0.0334 \\
\cline { 2 - 6 } & $<25$ & 68 & -0.3954 & 0.2443 & 0.0296 \\
\hline \multirow{2}{*}{ Absolute bias } & $>=25$ & 44 & 1.1978 & 0.3171 & 0.0478 \\
\cline { 2 - 6 } & $<25$ & 68 & 1.3212 & 0.2699 & 0.0327 \\
\hline
\end{tabular}

Table 4. Two-sample t-test bias difference according to chronological age

\begin{tabular}{|c|c|c|c|c|c|c|c|c|c|}
\hline \multicolumn{3}{|c|}{$\begin{array}{c}\text { Levene's Test for Equality of } \\
\text { Variances }\end{array}$} & \multicolumn{7}{|c|}{ t-test for Equality of Means } \\
\hline & \multirow[t]{2}{*}{$F$} & \multirow[t]{2}{*}{ Sig. } & \multirow[t]{2}{*}{$\mathrm{t}$} & \multirow[t]{2}{*}{ df } & \multirow[t]{2}{*}{$\begin{array}{l}\text { Sig. (2- } \\
\text { tailed) }\end{array}$} & \multirow[t]{2}{*}{$\begin{array}{l}\text { Mean } \\
\text { Diff. }\end{array}$} & \multirow[t]{2}{*}{$\begin{array}{l}\text { Std. Error } \\
\text { Difference }\end{array}$} & \multicolumn{2}{|c|}{$\begin{array}{c}\text { 95\% Confidence } \\
\text { Interval of the } \\
\text { Difference }\end{array}$} \\
\hline & & & & & & & & Lower & Upper \\
\hline $\begin{array}{c}\text { Early life cycle } \\
\text { phases bias }\end{array}$ & 1.005 & 0.318 & 2.07 & 110 & 0.041 & 0.094 & 0.0456 & 0.004 & 0.185 \\
\hline Absolute bias & 2.216 & 0.139 & -2.20 & 110 & 0.030 & -0.123 & 0.0560 & -0.234 & -0.012 \\
\hline
\end{tabular}


H3: There is difference in estimation bias between consultants and users of consulting services The data from our sample suggest that there is no statistically significant difference in estimation of bias between consultants and users of consulting service.

Significant differences were not found between early life cycle stages bias of consultants $(M=-0.374$, $\mathrm{SD}=0.26)$ and users of consulting services $(M=-0.368, \mathrm{SD}=0.22) ; \mathrm{t}(117)=0.475, \mathrm{p}=0.636$.

Also, absolute bias in organisations with less than 25 years of chronological age $(\mathrm{M}=1.32, \mathrm{SD}=0.27)$ and organisations with more than 25 years of chronological age $(M=1.20, S D=0.31)$ is significantly different $t(117)=-1.348, p=0.180$.

Table 5. Two samples according to estimator

\begin{tabular}{|l|c|r|r|r|r|}
\hline \multirow{3}{*}{ Early life cycle phases bias } & Consultants/users & N & Mean & Std. Deviation & Std. Error Mean \\
\cline { 2 - 6 } & Consultants & 64 & -0.3471 & 0.2569 & 0.0321 \\
\cline { 2 - 6 } & $\begin{array}{c}\text { User of consulting } \\
\text { services }\end{array}$ & 55 & -0.3682 & 0.2200 & 0.0297 \\
\hline \multirow{2}{*}{ Absolute bias } & Consultants & 64 & 1.2429 & 0.3040 & 0.0380 \\
\cline { 2 - 6 } & $\begin{array}{c}\text { User of consulting } \\
\text { services }\end{array}$ & 55 & 1.3152 & 0.2767 & 0.0373 \\
\hline
\end{tabular}

Table 6. Two-sample t-test of bias difference according to estimator

\begin{tabular}{|c|c|c|c|c|c|c|c|c|c|}
\hline \multicolumn{3}{|c|}{$\begin{array}{c}\text { Levene's Test for Equality of } \\
\text { Variances }\end{array}$} & \multicolumn{7}{|c|}{ t-test for Eqality of Means } \\
\hline & \multirow[t]{2}{*}{$\mathrm{F}$} & \multirow[t]{2}{*}{ Sig. } & \multirow[t]{2}{*}{$t$} & \multirow[t]{2}{*}{ df } & \multirow[t]{2}{*}{$\begin{array}{l}\text { Sig. } \\
(2- \\
\text { tailed) }\end{array}$} & \multirow[t]{2}{*}{$\begin{array}{c}\text { Mean } \\
\text { Difference }\end{array}$} & \multirow[t]{2}{*}{$\begin{array}{l}\text { Std. Error } \\
\text { Difference }\end{array}$} & \multicolumn{2}{|c|}{$\begin{array}{c}\text { 95\% Confidence } \\
\text { Interval of the } \\
\text { Difference }\end{array}$} \\
\hline & & & & & & & & Lower & Upper \\
\hline $\begin{array}{l}\text { Early life cycle } \\
\text { phases bias }\end{array}$ & 1.928 & 0.168 & 0.48 & 117 & 0.636 & 0.0210 & 0.0442 & -0.0666 & 0.1086 \\
\hline Absolute bias & 0.796 & 0.374 & -1.35 & 117 & 0.180 & -0.0723 & 0.0536 & -0.1785 & 0.0339 \\
\hline
\end{tabular}

\section{Discussion}

Our results show that there is considerable overall bias when engagement of consultant service is estimated in different life cycle phases of the organisation. Early life cycle phases are heavily underestimated, and actual engagement in those phases is much higher than estimated by our respondents. Early life cycle phases have more dynamic changes in structure, strategy, processes, structure of employees, culture and even management styles, values and skills, according to Downs (1967); Lippitt\&Schmitdt, (1967); Scott (1971); (Mueller,1972); Katz \& Kahn (1978); Adizes (1979); Quinn \& Cameron (1983); Lewis \& Churchill (1983); Miller \& Friesen (1984); Scott \& Bruce (1986); Whetten (1987); Walsh \& Dewar (1987); Phelps, Adams \& Bessant (2007); Sirmon, Hitt, Ireland \& Gilbert, (2011) as well as Hanks (2015). This research shows that consultant engagement is less expected in those early phases. Bias is very strong, and members of organisations founded less than 25 years ago make even $31.4 \%$ bigger mistake, expecting less chance of proactive consultant engagement in early phases. The dynamics of the early life cycle phases mean that there is more interaction, more action, which can be deducted from the need for more external information and knowledge. Consultants can interpret new ideas in an acceptable way and integrate them into managers and employees' daily work (Hu, Found, Williams \& Mason 2014). While previous research in the field is mostly descriptive, giving insights into states and behaviour characteristic for different life cycle phases, this research takes prescriptive direction, and suggests possible action lacking in the early life cycle phases. 


\begin{abstract}
Chronological age, according to our research, is manifested in less bias, both for early life cycle phases and absolute bias for all life cycle phases. That is in line with the previous research and general business wisdom presuming experience and organisational learning to come along with the chronological age of the organisation. On the other hand, more precise estimations of consultants were not confirmed by our sample. Even though consultants have much more experience in the engagement, there is no significant difference in the mistakes they make, either in early life cycle phases, or the absolute bias for the entire life cycle.
\end{abstract}

This can lead to another interesting metaphor, comparing young, entrepreneurial organisations with young persons. Youth (which is in both cases related to, but not determined by chronological age) is characterized by self-assurance and less worry for the future problems which do not manifest visibly. Thus, as we do not expect to see many young people having voluntary regular medical preventive exams, we do not expect much proactive consultant engagement in such organisations which did not have enough time to gather organisational experience. Timing for consultant engagement is not often correctly estimated by the users of the service, so those services can be engaged as preventive before issues arise in organisation and become a crisis at the tip of the organisational iceberg. Consulting can provide liminal space, as seen by Czarniawska\&Mazza (2003), during which usual practice and order are suspended and replaced by new rites and rituals. That fits the early life cycle phases, as described in the life cycle theory analysis according to previous research. Such practice can improve the survival rate of entrepreneurial organisations, and increase the level of entrepreneurial activity which was found to be not as good as it can be in the area, according to direct consulting experience (Krivokapic \& Jasko, 2015). Young organisations can benefit from different styles of consulting engagement, and in the light of different life cycle theories analysed in Table 1, most desirable will be the "Management Physician", "System Architect" and "Friendly Co-Pilot" as seen by Nees \& Greiner (1985).

\title{
Conclusions, Limitations and Future Research
}

The conclusions of our research show that there is a strong bias in estimation of engagement of proactive consulting services. People working in the organisations do not have a right perception on when consultant services should be engaged proactively, as this study has shown, especially during early life cycle phases. Generally, it is expected that the services should be engaged much less than they are actually engaged. That expectation implies another factor which influences and probably causes proactive consultant engagement. Our further inference is that organisations should cure that bias by engaging into more proactive consultant engagement during the early life cycle phases. Just as preventive medical exams can mean so much for the individuals, preventive engagement of external knowledge and estimations can be very useful for the organisations, especially in early life cycle phases. So it can be beneficial for organisations, especially in the early phases, to engage external advice, knowledge and help without apparent reason, just as a regular medical check-up. That engagement does not have to be a costly collaboration with world-class consulting firm, but it should provide external and expert opinion on potential issues in organisation before they manifest at the tip of the organisational iceberg.

The limitations of this research are mostly focused on the sample. Organisations providing data for Adizes Institute reports were not a true random sample - those organisations did search for proactive consulting services on their own, and we can observe self-selection bias. However, it is near to impossible to obtain tacit knowledge, information on important traits of the organisation such as culture, structure, core values, business results, internal conflicts, management styles, organisational behaviour without strong social capital and relationships with members of that organisation, or some kind of goodwill coming from the side of the researched organisation. Such knowledge, information and data are needed to estimate the life cycle, but at the same time can be sources of competitive advantage and organisations do not need, nor are they legally obliged to share a vast majority of that data. Insisting on a true random sample and methodological purity by expecting randomly chosen organisations to share intimate knowledge, information and data on possible sources of competitive advantage with the researcher indicate absolute ignorance on how organisations actually work and how the decisions are made in the organisational contexts. Also, a limitation is that our sample consists of organisations proactively searching for the consulting services so the results cannot be generalized on all consultant engagement. Further, our survey sample is from the Southeastern Europe, and our conclusions can be generalized only for that region, as well as, with somewhat lesser reliability, for the emerging economies in general.

Further research has a twofold direction. The first stream of research will be focused on extending the sample and improving generalizability of our conclusions. The second stream of research will be focused on extending the existing questionnaire in order to indicate factors which cause proactive consultant engagement in spite of the different expectations. We hope that our research will provide some answers for the theory and be proactive, but more than that we hope it will raise some new issues considering the nature of consultant engagement in emerging economies. 


\section{REFERENCES}

[1] Adizes, I.(1979). Organizational passages—diagnosing and treating life cycle problems of organizations. Organizational dynamics, 8(1), 3-25.DOI: 10.1016/0090-2616(79)90001-9

[2] Adizes, I. (2004). Managing corporate life cycles. The Adizes Institute Publishing.

[3] Adizes, I., Cudanov, M., \& Rodic, D. (2017). Timing of Proactive Organizational Consulting: Difference between Organizational Perception and Behaviour. Amfiteatru Economic, 19(44), 232-248.

[4] Bagozzi, R.P., Yi, Y. \& Phillips, L.W. (1991). Assessing construct validity in organizational research. Administrative science quarterly, 36(3) 421-458.DOI: 10.2307/2393203

[5] Bessant, J. \&Rush, H. (1995). Building bridges for innovation: the role of consultants in technology transfer.Research Policy, 24(1), 97-114.DOI: 10.1016/0048-7333(93)00751-E

[6] Boulding K.E. (1950), A Reconstruction of Economics. New York, USA: Wiley \& Sons, p. 34

[7] Bronnenmayer, M., Wirtz, B.W.\&Göttel, W.(2016). Determinants of perceived success in management consulting: An empirical investigation from the consultant perspective, Management Research Review,39(6), 706-738. DOI: 10.1108/MRR-06-2014-0145

[8] Cacioppe, R. \& Edwards, M. (2005). Seeking the Holy Grail of organisational development: A synthesis of integral theory, spiral dynamics, corporate transformation and action inquiry. Leadership \& Organization Development Journal, 26(2), 86-105.DOI: 10.1108/01437730510582536

[9] Czarniawska, B., \& Mazza, C. (2003). Consulting as a liminal space. Human relations, 56(3), 267-290.

[10] Cook, T.D., Campbell, D.T. \& Day, A. (1979). Quasi-experimentation: Design \& analysis issues for field settings. Boston, USA: Houghton Mifflin.

[11] Downs, A. (1967). Inside bureaucracy. Boston: Little, Brown, p. 264.

[12] Greiner, L.(1972). Evolution and Revolution as Organizations Grow, Harvard business review,50(3), 3746. DOI: $10.1007 / 978-1-349-20317-825$

[13] Gurianova, E. A., Gurianov, I. N., \&Mechtcheriakova, S. A. (2014). The influence of phase the organizational life cycle on organizational structure management and transaction costs. Asian Social Science, 10(20), 137.

[14] Haire, M.(1959). Biological models and empirical histories of the growth of organizations. In Haire, M. (Ed.) Modern Organizational Theory,(pp. 263-269). New York, USA: John Wiley.

[15] Hanks, S.H. (2015). The organization life cycle: Integrating content and process. Journal of Small Business Strategy, 1(1), 1-12.

[16] Hu, Q., Found, P., Williams, S., \& Mason, R. (2014). The role of consultants in organizational learning. Journal of Management Policy and Practice, 15(4), 29.

[17] Ionescu, G.G. \&Negrusa, A.L. (2007). The study about organizational life cycle models. Review of International Comparative Management, 8(4), 5-15.

[18] Katz, D. \& Kahn, R.L. (1978). Organizations and the system concept - Classics of organization theory, pp. 161-172.New York, USA: Thomson Learning.

[19] Kimberly, J.R.(1979) Issues in the creation of organizations: Initiation, innovation, and institutionalization. Academy of Management Journal, 22(3), 437-457.DOI: 10.2307/255737

[20] Kipping, M. \& Clark, T., 2012. The Oxford handbook of management consulting. Oxford, UK: Oxford University Press.

[21] Krishnaswamy, K. N., Sivakumar, A. I., \&Mathirajan, M.(2004). Management Research Methodology: Integration of Principles. Methods and Techniques, New Delhi, India: Dorling Kindersley Ltd.

[22] Krivokapić, J.,\& Jaško, O., 2015. Global Indicators Analysis and Consultancy Experience Insights into Correlation Between Entrepreneurial Activities and Business Environment. Amfiteatru Economic, 17(38), pp. 291-307

[23] Kubr, M. (2002). Management consulting: A guide to the profession. Geneva, SW: International Labour Organization.

[24] Lester, D.L., Parnell, J.A. \&Carraher, S.(2003). Organizational life cycle: A five-stage empirical scale. The International Journal of Organizational Analysis, 11(4), 339-354.DOI: 10.1108/eb028979

[25] Lewis, V.L.,\&Churchill, N.C. (1983). The five stages of small business growth. Harvard business review, 61(3), 30-50. DOI:

[26] Lippitt, G.L., \&Schmidt, W.H. (1967). Crises in a developing organization. Harvard Business Review, 45(11), 102-112.

[27] Lyden, F.J. (1975). Using Parsons' functional analysis in the study of public organizations.Administrative science quarterly, 59-70.DOI: 10.2307/2392123

[28] Marshall, A. (1890). Principles of political economy. Maxmillan, New York. 
[29] Masterpasqua, F.E. \&Perna, P.A. (1997). The psychological meaning of chaos: Translating theory into practice. Washington DC, USA: American Psychological Association.

[30] McLachlin, R.D.(1999). Factors for consulting engagement success. Management Decision, 37(5), 394404. DOI: $10.1108 / 00251749910274162$

[31] McLachlin, R.D.(2012). Service quality in consulting: what is engagement success?. Managing Service Quality: An International Journal. 10(3), 141-150, DOI:10.1108/09604520010336669

[32] Miller, D. \& Friesen, P.H.(1984). A longitudinal study of the corporate life cycle. Management science, 30(10), 1161-1183. DOI: 10.1287/mnsc.30.10.1161

[33] Mueller, D.C. (1972). A life cycle theory of the firm.The Journal of Industrial Economics, 20(3), 199219.DOI: $10.2307 / 2098055$

[34] Nees, D. B., \& Greiner, L. E. (1985). Seeing behind the look-alike management consultants. Organizational Dynamics, 13(3), 68-79.

[35] Phelps, R., Adams, R., \&Bessant, J., 2007. Life cycles of growing organizations: A review with implications for knowledge and learning. International Journal of Management Reviews, 9(1), 1-30.DOI: 10.1111/j.1468-2370.2007.00200.x

[36] Quinn, R.E., \&Cameron, K., 1983. Organizational life cycles and shifting criteria of effectiveness: Some preliminary evidence. Management science, 29(1), 33-51.DOI: 10.1287/mnsc.29.1.33

[37] Rooke, D.,\&Torbert, W.R.(1998). Organizational transformation as a function of CEO's developmental stage. Organization Development Journal, 16(1), p.11.

[38] Saris, W.E. \&Gallhofer, I.N.(2014). Design, evaluation, and analysis of questionnaires for survey research. 2nd edition. New York, USA: John Wiley \& Sons.

[39] Saunders, M., Lewis, P., \& Thornhill, A.(2011). Research methods for business students, 5th edition. Harlow, UK: Pearson Education.

[40] Scott, B.R. (1971).Stages of Corporate Development-Part 1, Case No. 9-371-294, , Boston, USA:Intercollegiate Case Clearing House.

[41] Scott, M.,\&Bruce, R.(1987). Five stages of growth in small business. Long range planning, 20(3), 4552.DOI: 10.1016/0024-6301(87)90071-9

[42] Sherman, F.T. \&Torbert, W.R. (2000). Transforming social inquiry, transforming social action: New paradigms for crossing the theory/practice divide in universities and communities. New York, USA: Springer Science \& Business Media. DOI: 10.1007/978-1-4615-4403-6

[43] Simon, A. \& Kumar, V. (2001). Clients' views on strategic capabilities which lead to management consulting success. Management Decision, 39(5), 362-372. DOI: 10.1108/EUM0000000005472

[44] Sirmon, D. G., Hitt, M. A., Ireland, R. D., \& Gilbert, B. A. (2011). Resource orchestration to create competitive advantage: Breadth, depth, and life cycle effects. Journal of Management, 37(5), 13901412. DOI: $10.1177 / 0149206310385695$

[45] Tam, S., \&Gray, D. E. (2016). Organisational learning and the organisational life cycle: the differentia aspects of an integrated relationship in SMEs. European Journal of Training and Development, 40(1), 2-20.

[46] Torbert, W.R. (1974). Pre-bureaucratic and post-bureaucratic stages of organization development.Interpersonal Development, 5(1), 1-25.

[47] Turner, A.N.(1981). Consulting is more than giving advice. Harvard business review, 60(5), 120-129.

[48] Von Bertalanffy, L. (1933) Modern Theories of Development: An Introduction to Theoretical Biology, Oxford University Press, New York, USA: Harper.

[49] Walsh, J.P., \&Dewar, R.D. (1987). Formalization and the organizational life cycle. Journal of Management Studies, 24(3), 215-231. DOI: 10.1111/j.1467-6486.1987.tb00700.x

[50] Weckowicz, T. (2000) Ludwig von Bertalanffy 1901-1972: A Pioneer of General Systems Theory. CSR Working Paper No. 89-23, Edmonton, Canada: University of Alberta Center for Systems Research.

[51] Werr, A. \&Stjernberg, T.(2003). Exploring management consulting firms as knowledge systems. Organization studies, 24(6), 881-908.DOI: 10.1177/0170840603024006004

[52] Whetten, D.A. (1987). Organizational growth and decline processes. Annual Review of Sociology, 13(1), 335-358. DOI: 10.1146/annurev.so.13.080187.002003

[53] Zeithaml, Valarie A., Parasuraman, A., \&Berry, L.L. (1990). Delivering quality service: Balancing customer perceptions and expectations. New York, USA: Simon and Schuster

[54] Zikmund, W., Babin, B., Carr, J. \&Griffin, M. (2012). Business research methods, 9th edition. Cincinnati, USA: South-Western College Pub. 


\section{$1 / 1 / 1 / 1 / 1 / 1 / 1 / 1 / 1 / 1 / 1 / 1 / 1 / 1 / 1 / /$ abouthe euthor}

Ichak Adizes

Adizes Institute, Santa Barbara, California, USA

info@adizes.com

Dr. Ichak Kalderon Adizes is widely acknowledged as one of the world's leading management experts and an internationally best-selling author. Over 48 years, he has developed and refined a methodology that enables corporations, governments, and complex organizations to accomplish exceptional results.Leadership Excellence Journal named him one of the Top 30 Thought Leaders in the United States, and Executive

Excellence Journal put him on their list of the Top 30 Consultants in America.

Dr. Adizes has received many honors, including 18 doctorates, citizenships in two Eastern European countries, the rank of honorary lieutenant colonel in the Israeli army and is a Fellow of the International Academy of Management. He also received the 2010 Ellis Island Medal of Honor. Dr. Adizes taught at the Columbia University Executive Program, served as a tenured faculty member at UCLAand was a visiting professor at Stanford, Tel Aviv, and

Hebrew Universities. He also served as Dean of the Adizes Graduate School and is currently an academic advisor to theRussian Federation's Academy of National Economy. In addition to consulting to prime ministers and cabinet-level officers throughout the world, Dr. Adizes has worked with a wide variety of companies ranging from startups to members of the Fortune 50. He lectures in four languages, and has appeared in more than 50 countries before well over 100,000 executives. He has written 24 books,translated into a combined total of over 31 languages. His bookCorporate Lifecycles: How Organizations Grow and Die and What to Do about It (subsequently revised, expanded and republished as Managing Corporate Lifecycles) was named one of the Ten Best Business Books by Library Journal. Dr. Adizes lives in Santa Barbara, California, with his family.

\section{Dušanka Rodić \\ Adizes Institute, Santa Barbara, California, USA dushka_rodic@hotmail.com}

Dušanka Rodić is a consultant in three fields of change management: organizational management, organizational culture and value system theory and practice with more than 8 yeas of practical experience working for companies in the regions of South East Europe, East Europe and the EU. She is certified by following consultant companies with unique methodologies: Adizes Institute, Hofstede and Spiral Dynamic. Dušanka Rodić has rich experience working for companies in many industries in many countries, where she mostly worked with top and middle management, which gave her the idea of exploring managerial decisions, style and value system in order to research this perspective of change, with the goal to change the world, as an idealist. Her current academic research addresses issues of managerial decisions and bias in certain stages of organisational development, organisational culture and entrepreneurship, managerial styles and values.

Mladen Čudanov
University of Belgrade, Faculty of Organizational Sciences
mladenc@fon.bg.ac.rs

Mladen Čudanov works as associate professor at the Faculty of Organizational Sciences, University of Belgrade. As an assistant professor, he was a visiting lecturer in the joint programs of the IVWA from Germany and Jiangsu College of Information Technologies at Wuxi and Zhuhai City Polytechnic colleges in China. His major research interests are ICT and organisational design, restructuring of business systems and organizational change. He has published more than 110 articles in scientific journals and at conferences, and works as editor and reviewer in several scientific journals, including Clarivate Analytics JCR journal Amfiteatru Economic.
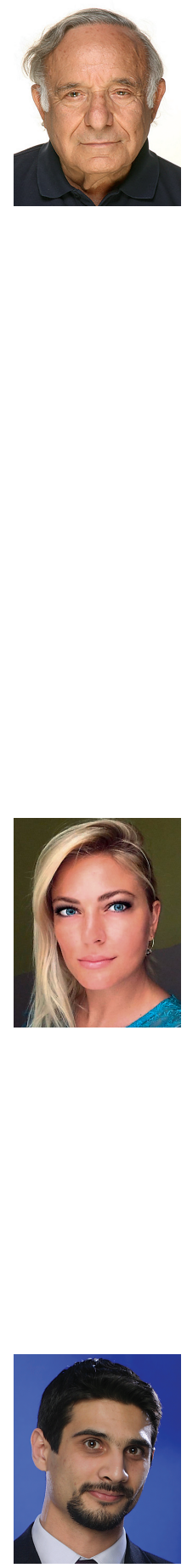